\title{
Güzin Abla Köșesi’nin \\ Akılcı Duygusal Davranışçı Yaklaşımın \\ Temel Kavramları Açısından İncelenmesi
}

\author{
Çağla KARADEMİR \\ Sakarya Üniversitesi, Eğitim Bilimleri Enstitüsü, 54300, \\ Hendek / Sakarya / Türkiye
}

\begin{abstract}
Özet
$\mathrm{Bu}$ araştırma, bir problemle karşı karşıya kalan bireylerin, yardım aramak için bir gazetenin Güzin Abla Köşesi’ne yazdıkları mektupların Akılcı Duygusal Davranışçı Yaklaşımın Temel Kavramları açısından incelenmesi amacıyla yapılmıştır. Araştırmanın modeli nitel araştırma yaklaşımlarından doküman analizidir. Araştırmaya konu olan verileri ulusal düzeyde yayın yapan bir gazetenin Güzin Abla Köşesi'ne 2011 yılında aşk ve ilişkiler konusunda gelen 5 okuyucu mektubu ve 5 cevap mektubu oluşturmuştur. Mektuplar, Akılcı Duygusal Davranışçı Yaklaşımın Temel Kavramları'ndan ABC Modeli, akılcı ve akıldışı düşünceler, sağlıklı ve sağlıksız duygular açısından incelenmiştir. Mektupların genellikle aşırı genelleştirme, dayatmacılık, felâketleştirme, olumsuza odaklanma, ikili düşünme (ya hep ya hiç), geleceği ön görme (falcılık), keyfî çıkarsama gibi akılcı olmayan pek çok inanç özelliğini içerdiği görülmüştür. İncelenen hemen hemen her mektup dayatmacı, zorunluluk


içeren ifadelerle noktalanmıştır. Güzin Abla'nın verdiği yanıtların, akılcı olmayan pek çok inanç içerdiği, bireylerin inanç sistemlerini değiştirip, farklı bakış açılarıyla olayları değerlendirip, daha akılcı inançlara sahip olabilmelerine yardımcı olabilecek nitelikte olmadığı görülmüştür.

Anahtar Kelimeler: Akılcı duygusal davranış̧̧ı yaklaşım; ABC modeli; Akılcı ve akıldışı inançlar; Sağlıklı ve sağlıksız olumsuz duygular; Güzin abla köşesi.

\title{
Investigating Güzin Abla Column's Rational Emotional Behavior Approach In Terms of Basic Concepts
}

\begin{abstract}
This research is faced with a problem of individuals, Güzin Abla column's wrote letters of a newspaper to call for help, Rational Emotive Behavioral Approaches were made in order to examine in terms of the basic concepts. The research design is a document analysis of the qualitative research approach. Survey data at the national level by publication of a newspaper Güzin Abla Column, which was published in 2011, about love and relationships 5 reader letters and 5 answer letters, examined in terms of the basic concepts of Rational Emotive Behavioral Approach the ABC Model, rational and irrational thoughts, healthy and unhealthy emotions. Letters are usually such as over-generalization, on force, catastrophizing, negative focus, binary thinking (all or nothing), the future of the front sight (fortune telling), arbitrary inference was found to have feature. Examined almost every letter concluded with including imposed and an obligation. The response of Güzin Abla observed that are included in many irrational beliefs, individuals to change belief systems, to evaluate the events from different, they may also be more rational beliefs was not qualified to help.
\end{abstract}

Keywords: Rational emotive behavioral approach; ABC model; rational and irrational beliefs; Healthy and unhealthy negative emotions; Güzin abla column. 


\section{Extended Summery}

\section{Purpose}

The Rational Emotibe Behavior Therapy which was started to be developed by Albert Ellis in 1955 as a theory of personality and a method of psychotherapy, claims that thought is the most important marker of the human emotions. Acording to REBT, people are born with both having a rational and non-rational potential. Rational beliefs help individual giving convenient reactionas when he is in trouble. But non-rational beliefs often cause non-functional inconvenient reactions (Ellis and Dryden, 1997). Non-rational comments ocur from the reality's being distorted and there are different kinds of distorting reality; All-or-nothing thinking (or dichotomous reasoning), overgeneralization, filtering, disqualifying the positive, mind reading, fortune-telling, magnification and minimization, catastrophizing, emotional reasoning, should statements, labeling, personalization, blaming (Köroğlu, 2011; Türkçapar, 2008). The ABC Model, whose aim is to Show clearly that inner speaking and hypothesis system are the main reasons of the settled thoughts, emotions and behaviours which are non-rational, is the centre of REBT. EBBT is to make a distinction between healthy positive emotions (love, happiness, joy, curiosity, etc...) and unhelthy negative emotions (sadness, regret, ennui, dissatisfaction etc...). People may need a pyshological support or help outside due to the effects of emotional problems. Individuals are able to demand help and support from Professional (formal source) or non-professional (informal source) persons about aid issue-one of these informal sources is the people who are on the column of newspaper and magazine. An example of this 
is the column of a newspaper "Güzin Abla" which broadcasts international. Individuals write their problems almost on every matter and ask for help with using nicknames on the column of the newspaper named "Güzin Abla". The responses related to problems are written on the column. Beeing a column which has only a few researches so far although it exists for a long time and its still beeing active, made it worth to examine.

\section{Method}

The datas on the research were examined from the methods of qualitative research through document analysis. The document consists of the analysis of written materials which include data about phenomenon or phenomenons aimed to study and search (Y1ldırım ve Şimşek, 2006). In the research made on the net archive of published newspaper of "Güzin Abla" column, there has been published 311 letters in 2011 and it has seen that 133 of them are about love and relations. In 2011, the letters that sent fort his column under the heading of love and relationships, separation lover, having a relationship with a married, abondonment, age differences, communication problem; and they are divided into 5 subcategories. Within these letters, 5 reader letters and 5 reply letters would have the opportunity to be examined in the terms of basic concepts of REBT ABC Model, rational beliefs, irrational beliefs, healthy and unhealthy negative emotions.

\section{Results}

It has seen that both the reader letters and Güzin Abla's replies generally have lost of irrational items about belief features. Letters 
generally were found to have lots of irrational beliefs such as over-generalization, on force, catastrophizing, negative focus, binary thinking (al lor nothing), the future of the front sight (fortune telling), arbitrary inference. Irrational replies were given for irrational letters. The column used solid and firmly style to tell them what to do, unlike given responses to improve the Outlook or to change it. Unlike the ABC Model, people connects their resultants to the events they lived, they ignore the impact of their thoughts and beliefs to the resultants, or they are not aware of. It has examined that on almost every letter there were terms with imposed and obligation.

\section{Discussion}

The column of Güzin Abla maintains its existence for a long time, and people supposes to have help for their problems throgh writing on that column. The reply letters for the reader letters related to love and relations usually have irrational beliefs features that may cause unhealthy negative emotions. Who has the responsibility of these reply letters that they are irrational, they have intellectual distortions and they have obstacles for he creative problem solving.

\section{Conclusion}

This is not an impact study; this is a study to investigate the effects on readers. But the result of the study shows that the letters sent to Güzin Abla column should be replied with the help of the experts in the field, and also it is important t1 suggest people to get the support of experts. 


\section{Giriş}

Stoacı filozof Epiktetos'un 'İnsanlara rahatsızlık veren, olayların kendisi değil, bu olaylara getirdikleri bakış açılarıdır." görüşü üzerine temellendirilen Akılc1-Duygusal Davranış Terapisi (Rational Emotive Behavior Therapy), bir kişilik kuramı ve psikoterapi yöntemi olarak Albert Ellis tarafından 1955 yılında geliştirilmeye başlamıştır (Ellis, 1995). Bilgi kuramına, değer yargılarına ve ahlâkî ilkelere dayalı olan akılcı duygusal davranış terapisi (ADDT), insanların duygularının en önemli belirleyicisinin biliş, diğer bir deyişle düşünce olduğunu savunur (Köroğlu, 2011; Türkçapar, 2008).

ADDT'ye göre, insanlar hem akılcı hem de akılcı olmayan bir potansiyele sahip olarak doğarlar. Akılcı inançlar, bireyin sıkıntılı zamanlarında uygun tepkiler vermesine yardımcı olurken akılcı olmayan inançlar sıklıkla işlevsel olmayan uygunsuz tepkilere yol açmaktadır (Ellis ve Dryden, 1997). Aile ve kültür de genellikle insanların mantıkdışı düşünme, kuruntulu düşünme ve tahammülsüz olma eğilimini arttırmaktadır (Çivitçi, Türküm, Duy ve Hamamc1, 2009, s.2). ADDT'nin temel kavramlarından bazılarının ABC Modeli, akılcı inançlar, akılcı olmayan inançlar ve sağlıklı ve sağliksız olumsuz duygular olduğu görülmektedir.

\section{ADDT'nin Bazı Temel Kavramları}

Aşağıda ADTT'nin temel kavramlarından olan akılcı inançlar, akılcı olmayan inançlar, ABC modeli ve sağlıklı ve sağlıksız duygular açıklanmıştır. 


\section{Akılcı Olan İnançlar:}

Akılcı inançlar; gerçekçidir, gerçeklikle tutarlıdır, kanıtlar tarafından desteklenebilir, mutlak emirler değildir, mantıklıdır, katı değil, esnektir, istekler, dilekler, beklentiler ve tercihlerden oluşur, üzüntü, sinirlenme, endişe gibi makûl duygulara yol açar, duygusal, davranışsal ve bilişsel sonuçları işlevseldir, bireyin amaçlarına ulaşmasına yardımcı olur (Dryden ve Neenan, 2004).

\section{Akılcı Olmayan İnançlar:}

Psikolojik rahatsızlığa yol açan akılcı olmayan inançların temelinde mutlak, katı zorunluluklar (-meli, - malı'lar) ve talepler bulunmaktadır (Ellis, 1994). Akılcı olmayan inançlar; gerçeklikle tutarlı değildir, mantıkdışıdır, katıdır, yanlıştır, hatalı çıkarımlara yol açar, emirler ve zorunluluklardan oluşur, sıklıkla aşırı genellemelere neden olur, depresyon, öfke, kaygı gibi sağlıksız olumsuz duygulara yol açar, duygusal, bilişsel ve davranışsal sonuçları işlevsel değildir, bireyin amaçlarına ulaşmasını engeller (Dryden ve Neenan, 2004). Gerçekliğin çarpıtılmasından oluşan akılcı olmayan inançlar düşünce hatalarından oluşur. S1k karşılaşılan düşünce hataları/düşünsel çarpıtmalar şunlardır:

1. Ya hep ya da hiç biçiminde (İkili) düşünme: Her şey siyah ya da beyaz olarak düşünülür. Çok iyi değilse çok kötü olduğu düşünülür.

2. Damgalama ve aşırı genelleme: Aşırı genelleme, sınırlı sayıda örneği temel alarak oluşturulmuş bir genel kurala inanmak ve bunu izlemektir. Damgalama (etiketleme) ise daha uygun ve gerçeği kapsayabilecek değerlendirmeler yapmak yerine kişinin 
kendisine veya diğerlerine genel etiketler yapıştırması ve bütün durumu bu nitelemenin 1şığında değerlendirmesi.

3. Bir sonuç çıkarıverme ya da daha önce söylenenlerle ilgisiz olumsuz birtakım sonuçlar çıkarma (keyfî çıkarsama): Böyle bir sonuç çıkarmayı sağlayan veriler olmamasına karşın her şey olumsuz olarak yorumlanır.

4. Olumsuza odaklanma: Olumsuz tek bir ayrıntı, bütünün içinden ayıklanır, çekilip öne çıkarılır ve yalnızca buna odaklanılır, artık resmin bütünü görülmez olur.

5. Olumluyu görmezden gelme (büyütme ve küçültme): Olumlu yaşantılar "sayılmaz" ya da bunlar yadsınır.

6. Yazgıyı anlama, geleceği öngördügünü düşünme (falcılık yapma): Her şeyin kötüye dönüşeceği öngörülür. Felâketleştirme, olması muhtemel diğer sonuçları hesaba katmaksızın geleceği hep olumsuz olarak öngörme. Küçük bir kanıttan yola çıkarak o kanıtı da yeterince değerlendirmeden ve olması muhtemel diğer sonuçları hesaba katmaksızın durumu hep olumsuz olarak öngörme.

7. Duygusal çıkarımlarda bulunma: Olayların yarattığı olumsuz duyguların gerçeği yansıttığı düşünülür.

8. Kişiselleştirme: Kişinin tam denetiminde olmayan bir olay için kendini sorumlu tuttuğu zaman ortaya çıkar.

9. Küçümseme: Kişi, iyi ve güzel niteliklerini küçümser, sorunlarını ve kısıtlılıklarını gözünde büyütür.

10. "Düzmeci” göründüğünü düşünme: Kişinin başarılarına ve olumlu yanlarına kendinin bile inanamaması ve bunların gerçeğin 
dışavurumu olmadığgnı düşünmesi.

11. Yetkincilik: Hiçbir eksiği olmamasının peşinde koşma, tersine katlanamadığını düşünmedir.

12. Zorunluluk ifadeleri: -Meli, -malı düşünce tarzı adı da verilen bu düşünce biçiminde kişinin kendisinin, diğerlerinin nasıl davranması ve dünyanın nasıl olması gerektiği konusunda katı kuralları vardır.

13. Zihin okuma: Diğer insanların düşündüğünü bildiğimize ve onların da bizim ne düşündüğümüzü bildiklerine, bilmeleri gerektiğine inanmak (Köroğlu, 2011; Türkçapar, 2008).

\section{ABC Modeli:}

ABC Modeli ADDT'nin merkezi durumundadır (Corey, 2008). $\mathrm{ABC}$ şemasının oluşturulmasının amacı; içsel konuşmanın ve varsayım sisteminin, akılcı olmayan yerleşik düşüncelerin, duygu ve davranışların temel nedeni olduğunu açıkça göstermektir. Böylece, $A B C$ şeması ile insanların yarattıkları duygusal tepki ve bozulmalardan kendilerinin sorumlu olduğu gösterilmeye çalışılmaktadır (Dryden ve Gordon'dan akt. Oğurlu, 2006).

ABC Modeli, insanların istenmeyen harekete geçirici olaylarla (activating events) karşılaştıkları (A), bu uyarıcılara karşı akılcı ve akılcı olmayan inançlara sahip oldukları (B), akılcı inançları ile uygun duygusal ve davranışsal sonuçlar (C) yarattıkları ya da akılcı olmayan inançları ile uygun olmayan ve işlevsel olmayan sonuçlar (C) yarattıklarını belirtmektedir (Ellis, 1994). A noktasında harekete geçirici olay veya deneyim (Activating event or activating experience) yer alır. 
Bunlar genellikle bazı sevimsiz veya talihsiz çevresel olaylara ilişkin alg1larımızdir (Altun, 2006).

C noktasında duygusal ve davranışsal sonuçlar (Consequence) bulunur. Bunlar bireyi yardım almaya iten, rahatsızlık verici tepkilerdir. C, bireyin A'ya yönelik inanç sisteminin sonucunda ortaya çıkan duygu, düşünce ve davranışlardır (Altun, 2006; Akın, 2009).

B noktası ise bireylerin inanç sistemlerini (Belief) temsil eder. B olayla ilgili yerleşik düşünceler; olaya yüklenen anlamdır. B'deki düşünceler/inançlar A noktasında meydana gelen durumla ilgili olarak akılcı, mantıklı, gerçekçi olabileceği gibi akılcı olmayan inançlardan da oluşabilir (Altun, 2006; Corey, 2008; Çivitçi, vd., 2009; Köroğlu, 2011; Nelson-Jones, 1982).

ADDT'de duygusal, davranışsal ve bilişsel sonuçların (C) bireyin dışındaki bir kişinin davranışı, tutumu veya bir olayın (A) sonucu olmadığını; sonuçların, kişinin (A) ile ilgili inançlarından yani fikirlerinden, çıkarımlarından ve değerlendirmelerinden (B) kaynaklandığı vurgulanır (Ziegler, 2003).

\section{Sağlıklı ve Sağlıksız Duygular:}

ADDT, sağlıkl1-uygun duygular ile sağlıksız-uygun olmayan duygular arasında bir ayırım yapmaktadır. Sağlıklı duygular, hem istekleri, dilekleri ve tercihleri vurgulayan duyguları hem de bireyin istekleri engellendiği zaman doğal olarak oluşan duyguları ifade etmektedir. Sağlıklı olumlu duygular, sevgi, mutluluk, keyif, merak gibi duyguları; sağlıksız olumsuz duygular ise üzüntü, pişmanlık, can s1- 
kıntısı, hoşnutsuzluk gibi duyguları içermektedir. Bu duygular hayatta neyin daha az ve neyin daha çok istenip elde edileceği konusunda bireyi motive eder. Depresyon, kayg1, umutsuzluk, yetersizlik, değersizlik gibi duygular sağlıksız olumsuz duygular olarak görülür. Bu duygular sadece olumsuz şartları değiştirme konusunda bireye yardım etmemekle kalmaz, aynı zamanda bu şartları daha kötüye de yönlendirir (Çivitçi, vd., 2009).

Sağlıklı olmayan olumsuz duygulara, fizyolojik açıdan, birçok otonom sinir sistemi belirtisi eşlik eder. Davranışsal açıdan, kişinin kendisine zarar veren birtakım davranışlara yol açabilirler ya da kişinin sorun çözme becerilerini ketleyebilirler; dolayısıyla kişi kitlenip kalmış, sıkışmış, çaresiz, eli kolu bağlı bir durumda kalabilir. Bilişsel açıdan, aşırı yüklü, akılcı olmayan düşüncelerle birlikte bulunurlar (Köroğlu, 2011).

\section{Yardım Arama Davranışı ve Güzin Abla Köşesi}

Ellis (2002), duygusal sorunların temelinde mantıksız inançların olduğunu belirtmektedir. İnsanlar yaşadıkları duygusal sorunların etkisi ile dışarıdan bir psikolojik desteğe ya da yardıma gereksinim duyabilirler. Yardım arama, bireylerin içinde bulundukları, üstesinden gelemedikleri sorunlarla baş etmek amacıyla yardım konusu ile ilgili profesyonel ya da profesyonel olmayan bireylerden yardım ve destek talep etmesidir (Husaini, Moore ve Cain, 1994). Burada önemli olan karş1daki uygun kişilerden yardım talep edebilmektir. Bir başka deyişle yardıma gereksinim duyanların toplumdaki kaynakları fark edip yardım isteğinde bulunması gerekmektedir. Yardım arama davranışı, tıbbî 
sağlık hizmetlerinin verildiği merkezlere başvuru şeklinde olabileceği gibi, hocalar, büyücüler ve bitkisel şifacılar gibi tıp dışı kişilerle temasa geçme şeklinde de olabilmektedir (Özkorumak, Güleç, Köse, Borckardt ve Sayar, 2006).

Toplumumuzda bir yandan profesyonel kişilerden yardım arama davranışı devam ederken, bir yandan da sosyo-kültürel faktörlerin etkisi ile birlikte geleneksel yardım arama yöntemlerinin sürdüğü görülmektedir (Hamamcı, Murat, Yıkılmaz ve Çekiç, 2008). Ünal, Kaya ve Yalvaç (2007) tarafından yapılan bir çalışmada psikiyatri kliniğine başvuran hastaların \% 12,3'ünün geleneksel çareler aradığı, \% 32,5'inin de psikiyatri kliniklerine başvurdukları bulunmuştur. Özkorumak ve diğerleri (2006) tarafindan gerçekleştirilen bir başka araştırmada da depresyon hastalarının \% 24'ünün tıp dışı yardım arama davranışı içinde oldukları belirlenmiştir. Bir başka araştırmada hastaların geleneksel yardım arama davranışları incelenmiş, \% 26,9'unun psikiyatriste ve \% 36,52'sinin doktor dışı kişilere başvurdukları saptanmıştır (Yaşan ve Gürgen, 2004). Bir internet sitesinde "Psikolog veya psikiyatriye gidememenizin en önemli nedeni nedir?” diye sorulmuş ve ankete 2006 ve 2009 yılları arasında 38723 kişi katılmıştır. Ankete katılanlar, danışma ücretlerinin çok yüksek olmasını (\% 65.18), kime gideceğini bilememeyi (\% 13.82), psikolog ve psikiyatristlere güvenmemeyi (\% 8.66), damgalanmaktan korkmayı (\% 7.06), yaşadığ 1 yerde bulunmamasını (\% 5.28) sebep olarak göstermişlerdir (Psikoloji Portalı, 2010, May1s, 13).

Kişiler, zaman zaman gazete ve dergi köşelerinde yer alan kişi- 
lerden de yardım isteyebilmektedir. Bunun bir örneği de uzun süredir devam etmekte olan bir gazetenin "Güzin Abla" köşesidir. Burada gazetenin okuyucuları, Güzin Abla olarak isimlendirilen kişiye başvurarak sorunları nedeniyle yardım istemekte ve köşede de soruna yönelik cevaplar yazılmaktadır (Hamamcı ve diğ., 2008).

Bireyler, rumuz kullanarak hemen hemen her konuda sorunlarını yazmakta ve yardım talep etmektedir. Uzun yıllardır devam eden bu yardım arama ve yardım etme davranışı ile ilgili olarak yapılmış çok az araştırma bulunmaktadır.

Güzin Abla Köşesi'nin Aydın (akt; Avcı, 2003) tarafından 14 ay boyunca izlendiği ve konularına göre tasnif edildiği bir araştırmanın sonuçlarına göre köşede sıklıkla "erkeklere güvenilmez" yargısının dile getirildiği ve köşede, kadın mektup sahiplerinin uzlaşmaya, mes’eleleri tatlılıkla hâlletmeye, karşısındakinin üstüne varmamaya davet edildiği sonuçlarına ulaşılmıştır. Analiz sonucunda, ayrılık acısı çeken kadınlara: "Sabırlı ol." gibi pasif, erkeklere: "Git tekrar konuş." gibi daha girişken yöntemler önerilirken, aldatan eğer erkekse, onun: "O ünlü bunalım, zaman zaman böyle şeylere heveslenirler." diye üstü kapalı ifadelerle andropoza girdiği belirtilirken, aldatan eş eğer kadınsa, duruma göre "hoppa veya aile zoruyla evlendirilmiş kurban" olarak değerlendirilmiştir.

Bir başka araştırmada, Hamamcı ve diğerleri (2008) tarafından 1999-2007 yılları arasında Güzin Abla Köşesi’ne mektupla başvuran bireylerin kişisel özellikleri, sorun alanları ve okuyucu mektuplarına 
verilen yazılı yanıtların içeriği kullanılan yardım becerileri açısından içerik analizi yöntemi ile incelenmiştir. Yapılan incelemede, Güzin Abla Köşesi'ne başvuranların çoğunluğunun kadın ve bekâr olduğu, yaş dağılımlarının 14-50 arasında değiştiği bulunmuştur. Sorun alanları açısından bireylerin en çok duygusal ilişkiler ve evlilik ilişkilerinde yaşanan problemler nedeniyle Güzin Abla Köşesi'ne başvurdukları belirlenmiştir. Mektuplara verilen yanıtların yardım becerileri açısından sonuçlarında en çok sırasıyla tavsiye, yorum ve bilgi verme içeriği belirlenmiştir.

Uzun yıllardır varlığını sürdüren bir köşe hakkında çok az sayıda araştırma yapılmış olması ve köşenin hâlen etkinliğini sürdürüyor olması konunun incelenmeye değer olduğunu düşündürtmüştür.

\section{Yöntem}

\section{Araştırmanın Amacı}

$\mathrm{Bu}$ araştırma ulusal düzeyde yayın yapan ve 40 yılın üzerinde bir zamandır varlığını sürdüren ve insanların yaşadıkları problemler karşısında yardım aramak için başvurdukları bir köşe olan Güzin Abla Köşesi'ne gelen okuyucu mektuplarının ve cevap mektuplarının ADDT'nin temel kavramlarından olan ABC modeli, akılcı ve akılcı olmayan inançlar ve sağlıklı ve sağlıksız duygular açısından incelenmesi amacıyla yapılmıştır.

\section{Araştırma Modeli}

Araştırmada veriler, nitel araştırma yöntemlerinden doküman analizi yoluyla incelenmiştir. Doküman incelemesi, araştırılması he- 
deflenen olgu veya olgular hakkında bilgi içeren yazılı materyallerin analizini kapsamaktadır (Yıldırım ve Şimşek, 2003).

Güzin Abla Köşesi'nin yayımlandığı gazetenin internet arşivinde yapılan incelemede, adı geçen köşede 2011 yılı içerisinde toplam 311 mektubun yayınlandığı, bu mektuplardan 133 tanesinin aşk ve ilişkiler konusunda olduğu görülmüştür. Bu mektuplar, sevgiliden ayrılma, evli birisi ile ilişki yaşama, terk edilme, yaş fark1, iletişim problemleri olmak üzere 5 alt kategoriye ayrılmış ve bunların içerisinde inceleme firsat1 verebilecek nitelikte olan 5 okuyucu mektubu ve 5 cevap mektubu, ADDT'nin temel kavramlarından ABC Modeli, akılcı olan inançlar, akılcı olmayan inançlar ve sağlıklı ve sağlıssız olumsuz duygular açısından incelenmiştir.

\section{Bulgular ve Yorumlar}

Aşağıda incelenen mektuplar ve mektupların ADDT'nin temel kavramlarıyla ilgili bulgulara yer verilmiştir.

\section{Birinci Mektup (25 Ocak 2011)}

İki yıl ilişki yaşadıktan sonra sevgilim beni terk etti. Onsuz olmak, kendimi annesinden ayrılmış çaresiz bir çocuk gibi hissetmeme neden oluyor.

Sevgili ablacığım, benim çok sevdiğim biri var. Ama onun beni sevip sevmediğini bilmiyorum. İki yıl ilişsi yaşadık. Bana, benimle evlenmek istediğini söylemişti. "Seni asla bırakmayacağım” demişti. Ama sonra beni terk etti, ayrılırken de beni oyaladığını, benimle evlenmeyeceğini söyledi. İnanmak istemiyorum; ama ya doğru söylediyse? Bu, bana çok acı veriyor. Sanki boğazımda bir düğüm var, kalbim parçalanıyor. Yüzüm karıncalanıyor, bazen nefes almakta zorlandığımı hissediyorum. Onun için bütün arkadaşlarımı sildim. O sadece sevgili değildi benim için. Tek arkadaşım, yoldaşım, sırdaşım, kankam, annem, babam her şeyimdi... İçinde onun olmadığı tek bir hayal bile kurmamıştım. Şimdi sürekli ağlıyorum, kendimi çok güçsüz hissediyorum. Korkuyorum hem de çok korkuyorum... Nasıl düzelebilirim ablacığım? A $\breve{g}-$ 
lamak istemiyorum artık. Ne olur yardım edin bana, bir yol gösterin. Onsuz olmak, kendimi annesinden ayrılmış çaresiz bir çocuk gibi hissetmeme neden oluyor (Güzin Abla, 2011, Ocak, 25).

Birinci Mektubun ADDT'nin Temel Kavramları Açısından

\section{İncelenmesi}

A-Başlatan Olay: Çok sevilen sevgiliden ayrılma

C-Sonuç: Terk edilme, çaresizlik, incinme, acı çekme, ağlama, korku

B-İnanç: Beni asla bırakmayacaktı, ona inanmıştım, beni oyalamış, inanamıyorum, ya doğruysa, onun için çok şey yaptım, her şeyimdi, bütün hayallerimde o vardı, güçsüzüm.

Kişi, yaşadığı olay sonucunda pek çok duygu yaşadığını ifade etmiştir. Kişinin yaşadığı duygular sağlıklı olmayan olumsuz duygulardır ve düşünce biçimi akılcı değildir. Kişinin yaşadığ 1 çaresizlik, incinme, değersizlik, kaygı gibi duygular, yaşadığı olayın olumsuz yanlarını abartmasına, kendisine yardım edemeyeceğini düşünmesine, gelecekte acı çekeceğini düşünmesine, yaşadığını düşündüğü haksızlığı gözünde büyütmesine yol açabilecek bilişsel sonuçlara sahiptir. Kişinin yaşadığı sağlıklı olmayan olumsuz duygulara fizyolojik pek çok belirtinin de eşlik ettiği görülmektedir. (Sanki boğazımda bir düğüm var, kalbim parçalanıyor. Yüzüm karıncalanıyor, bazen nefes almakta zorlandığımı hissediyorum.)

Ayrıca kişinin ifadelerinin katılık, kesinlik, aşırı genelleştirmeler içeren akılcı olmayan inançlardan oluştuğu görülmektedir. (Bütün arkadaşlarımı sildim, her şeyimdi... İçinde onun olmadığı tek bir hayal bile kurmamıştım.). Kişi yaşadığg olayın yarattığı olumsuz duyguların 
etkisi ile duygusal çıkarımlarda bulunmakta ve "İçinde onun olmadığı tek bir hayal bile kurmamıştım." şeklindeki ifadeleri ile hayatına dâir diğer sonuçları hesaba katmaksızın felâketleştirme yaptığı görülmektedir.

\section{Birinci Mektuba Güzin Abla'nın Yanıtı}

Sevgili kızım, üzüntünü çok iyi anlıyorum. İnsan sevdiğini kaybettiğinde, kolunu ya da bacağını kaybetmiş, yarım kalmış gibi hisseder kendini. Ancak inan bana, bütün bunlar geçiyor. Geçmesi gerekiyor. Çünkü hiçbir insan ömür boyu böyle bir acıyla yaşayamaz. Sana söylemek istediğim çok önemli bir şey daha var. Hiç kimseyi; ama hiç kimseyi böyle kendini bütün dünyadan soyutlayacak şekilde sevme. İnsanlar fânidir kızım, birini yerine hiç kimseyi koyamayacak kadar çok seversen, onu kaybettiğinde hayatta tutunacak hiçbir şey bulamazsın. Bu da sonun olur. Allah, insana büyük bir özellik vermiş, şükür ki vermiş: Unutabilmek! Ne olursa olsun, hayatımızda iyi ya da kötü, önemli ya da önemsiz, acı ya da tatlı her şeyi zaman içinde unutuyoruz. Bu nedenle büyüklerimiz: "Zaman her şeyin ilacıdır" demiş. Ve bana kalırsa bu gençten ayrılman senin için hayırlı olmuş. Çünkü o seni, asla senin onu sevdiğin gibi sevmemiş (Güzin Abla, 2011, Ocak, 25).

\section{Birinci Mektuba Güzin Abla'nın Verdiği Yanıtın ADDT'nin}

\section{Temel Kavramları Açısından İncelenmesi}

Güzin Abla'nın yanıtının büyük ölçüde katı, hatalı çıkarımlara yol açabilecek emirler ve zorunluluklar içeren akıldışı inançlardan oluştuğu görülmektedir. Kesin, zorlayıcı ve zorunluluk içeren "İnsan sevdiğini kaybettiğinde, kolunu ya da bacağını kaybetmiş, yarım kalmış gibi hisseder kendini... Geçmesi gerekiyor..." ifadeleri ile aşırı genelleme yapıldığı, bu durumun temel bir kuralmış gibi sunulduğu görülmektedir. "...Bu da sonun olur" ifadesi ile olması muhtemel diğer sonuçlar hesaba katılmaksızın, gelecek olumsuz olarak öngörülmüş, felâketleştirme yapılmıştır. Aynı zamanda aşırı genelleme yapılarak, diğer kişinin düşünceleri okunmaya çalışılmış (asla senin onu sevdiğin 
gibi sevmemiş) ve gelecek öngörülmeye çalışılmıştır. ( $O$ kişiden ayrılman hayırlı olmuş...).

\section{İkinci Mektup (3 Ocak 2011)}

18 yaşında bir genç kızım. Bir süre önce sevgilimin evli olduğunu öğrendim. Ama buna rağmen ondan kopamıyorum.

Ben 18 aydır biriyle beraberim. İyi ve düzeyli bir ilişskimiz var. Yalnız kendisi üç aydır çok tuhaf davranmaya başladı. Eskisi gibi benimle ilgilenmiyor, sadece ben arayınca arıyor ya da ben mesaj yazınca yaz1yor. Kendisine birçok kez sordum nedenini. Sonunda evli olduğu ortaya çıktı ablacığım. Çok üzgünüm; ama beni çok sevdiğini ve asla bırakmayacağını söyledi. Ben de onu çok seviyorum. Ona çok bağlandım ve onsuz bir ân bile yapamam. Benden evli olduğunu sakladığ hâlde ondan ayrılamıyorum. Çok istedim düşündüm ayrılmayı; ama yapamadım. Eşiyle mutlu olmadığını söyledi; benim yanımda daha mutluymuş. Bir süre ayrıldık; ama iki hafta sürdü, sonra tekrar buldu beni ve hâlâ beraberiz. Elimden gelen her şeyi yaptım ondan soğumak için; ama olmuyor. Kendimden utanıyorum ablacığım, yuva yıkan durumunda olmak istemiyorum. Ayrıca kendisinden şüphe de ediyorum. Aramızda bir başkasının da olduğunu sanıyorum; çünkü zaman zaman çok tuhaf davranıyor. Sordum kendisine "Başkası varsa ben yokum" dedim. O da başka birinin olmadığını, çok yanlış düşündüğümü, söyledi. "Başkası olsa sana söylerdim, merak etme" dedi. Ne yapacağımı bilmiyorum, lütfen bir akıl verin (Güzin Abla, 2011, Ocak, $3)$.

\section{İkinci Mektubun ADDT'nin Temel Kavramları Açısından}

\section{İncelenmesi}

A-Başlatan Olay: Birlikte olduğu kişinin evli olması

C-Sonuç: Ayrılamama, üzüntü, utanma, güvensizlik, kararsızlık

B-İnanç: Tuhaf davranıyorsa başka birisi vardır, onsuz yapamam,

beni bırakmayacak, ona bağlıyım, beni çok seviyor, ayrılmalıyım, benimle mutlu eşiyle mutsuz, ondan soğuyamıyorum, çabaladım, yuva yıkıyorum.

Kişinin inançlarının yetersizlik içeren, hatalı çıkarımlara yol açan, zorunluluklar ve dayatmacı ifadeler içeren akılcı olmayan dü- 
şüncelerden oluştuğu görülmektedir. Kişinin, her şey ya siyahtır ya beyazdır biçiminde ya hep ya hiç biçimde düşündüğü, zorunlulukları içeren kesin/katı ifadeler içeren düşünce hatalarına sahip olduğu görülmektedir (Başkası varsa ben yokum, onsuz bir ân bile yaşayamam). Ayrıca keyfî çıkarsama yapılmış kişi elinde yeterince delil olmamasına rağmen sevgilisi tarafından aldatıldığını düşünmüştür. Kişinin yaşadığını belirttiği üzüntü duygusu sağlıklı olumsuz bir duygudur. Yaşadığı durumun hem olumlu hem de olumsuz yanlarını görebilir, kendisine yardımcı olabilir ve geleceğe umutla bakabilir. Bunun yanı sıra kişinin yaşadığını ifade ettiği utanma duygusu ise sağlıklı olmayan olumsuz bir duygudur. Akılcı değildir. Bilişsel sonuçları açısından utanma duygusu, bireyin yaşadığı olayın "utanılır”'lığını gözünde büyütmesine ve başkalarının onu aşağı görerek ondan sakınacakları yönünde çıkarımlarda bulunmasina neden olabilir.

\section{İkinci Mektuba Güzin Abla'nın Yanıtı}

Güzel kızım, sanki tek sorun, başka birisinin olmasıymış gibi, bunu kafana takmışsın. Sana aylarca evli olduğunu söylemeyen, bu ciddi konuyu senden saklayan birinin hayatında başka biri daha olsa, ne olacak sanki... Asıl önemli sorunu bir kenara bırakmış, olasılıklar üzerinde duruyor, kendine bunu dert ediniyorsun. Açıkçası sevdiğin adamın evli olmasını artık önemsemez gibisin. Kızım yuva yıkmak istemiyorum, derken samimi misin Allah aşkına... Bu adamın hayatında belki de senden başka birçok kadın vardır. Ama önemli olan senin böyle bir çözümsüzlüğün içinde yer alman, evli bir erkekle asla geleceği olmayan bir ilişkiyi, kendine göre sevgi diye adlandırdığın bir nedenin ardına sığınarak, sürdürmen. Bunu hiç hoş karşılamadım; çünkü önce seni düşünüyor, hayatını heba etmenden rahatsızlık duyuyorum (Güzin Abla, 2011, Ocak, 3).

\section{İkinci Mektuba Güzin Abla'nın Verdiği Yanıtın ADDT'nin Temel Kavramları Açısından İncelenmesi}

Güzin Abla'nın mektubunun da akılcı olmayan düşüncelerle ya- 
zıldığg1, kesin, katı zorlayıcı ifadelerden oluştuğu görülmektedir. Mektupta kişi bu ilişkiye devam ederse her şeyin kötüye döneceği öngörülmüş, falcılık yapılmıştır. Cevap mektubunda, kişinin hayatını heba edeceği, bir çözümsüzlüğün içerisinde olduğu, kişinin yaşadığ ilişkinin asla geleceği olmayan bir ilişki olduğu düşünülmekte, böylece kişinin geleceği okunmakta, olay korkunç görülmekte, felâketleştirme yapılmaktadır. Ayrıca "Bunu hiç hoş karşılamadım." ifadesi de sert, katı ve zorlayıcı bir akılcı inanç göstergesidir.

\section{Üçüncü Mektup (1 Şubat 2011)}

Sekiz yıldır birlikte olduğum sevgilim beni çok sevdiğini söylüyor. Ama evli ve karısından boşanmaya da yanaşmıyor.

Güzin Ablacığım, 26 yaşındayım ve sekiz yıllık bir birlikteliğim var. Sevgilim evli; ama biz de her şey yaşadık, evli gibiyiz. Beni çok seviyor, çok kıskanıyor. Ama karısını da bırakmıyor. Yine de haftada dört gün beraberiz. Birlikte çok güzel vakit geçiriyoruz, her yere gidiyoruz. Sürekli yanımda olsun istiyorum, onsuz yapamıyorum; ama karısını bırakmadığı için de sürekli tartışıyoruz. Beni hiç anlamıyor. Karısı da biliyor ilişkimizi. Birkaç yıl önce her şeyi öğrenmiş. Sevgilimi çok s1kıyor. O da bu yüzden yanımda eskisi kadar kalamıyor. Biz birlikteyken, sevgilimin telefonuna karısından mesajlar geliyor. Bana belli etmese de canının sıkıldığını görüyorum. Bazen eşiyle kavga edince, birlikte kalıyoruz. Yanımda huzur bulduğunu ve beni çok sevdiğini söylüyor. Ama beni seviyorsa karısını bırakması gerektiğini söylediğimde aldırış etmiyor. Niyetinin benimle evlenmek olmadığını düşünüyorum artık. Bu arada bir yanlışa daha düştüm. Yeni biriyle tanıştım, o da evli maalesef. Bir süre telefonda görüştük, sonra birkaç kez buluştuk. İlişkimiz henüz çok yeni, ona karşı bir şey hissetmiyorum. İkisinin de birbirinden haberi yok; olsaydı hiç hoş olmazdı. İki ilişsi yaşamama rağmen kendimi yalnız hissediyorum. Sekiz yıllık beraberliğimi de bitiremiyorum. Çok denedim; ama başaramadım. Aslında, sanırım bırakmak istemiyorum... Kafam karma karışı, ne yapmam gerekiyor? (Güzin Abla, 2011, Şubat, 1).

\section{Üçüncü Mektubun ADDT'nin Temel Kavramları Açısından}

\section{İncelenmesi}

A-Başlatan Olay: 8 yıldır birlikte olduğu sevgilisinin evli olması 
C-Sonuç: Kararsızlık, ilişkisiyle ilgili olarak tasalanma, çatışma yaşama

B-İnanç: Beni çok seviyor, kıskanç, onunla çok güzel zaman geçiriyorum, onsuz yapamam, sürekli tartışıyoruz, beni anlamıyor, karısından dolayı canı çok sıkkın, benimle huzurlu, benimle evlenmek istemiyor, ayrılamam, yalnızım, başaramadım, bırakmak istemiyorum.

Kişinin inançları akılcı olmayan inanç ögeleri taşımaktadır. Kişi, "Onsuz yapamam, ayrllamam." ifadeleri ile ya hep ya hiç biçiminde düşünmekte, bu durumda felâketleştirmeye yol açmaktadır. Aynı zamanda "ayrılamam, yapamam" ifadeleri aşırı genelleştirme içeren, katı, kesin ve zorlayıcı ifadelerdir. Kişinin ilişkisiyle ilgili olarak tasalanması (başka birinden ötürü kişinin ilişkisinin zora düşüyormuş gibi olması) sağlıklı olumsuz bir duygudur ve düşünce biçimi sağlıklıdır. Ortada somut bir neden vardır ve bundan dolayı ilişkisinin zorda olduğunu düşünmektedir.

\section{Üçüncü Mektuba Güzin Abla'nın Yanıtı}

Ah sevgili kızım, hangi yanlışından başlasam... Her şeyden önce,
sekiz yıldır senin hayatını çalan bu adamın hâlâ seninle evlenece-
ğini gerçekten ümit ediyor musun?
İkincisi ise sanki bu adam üzerinde senin karısından çok daha fazla
hakkın varmış, sanki sen karısıymıssın da o sevgilisiymiş gibi düşü-
nüyorsun. Sizi rahatsız etmesinden yakınıyorsun. Hiç kendini o ka-
dıncağızın yerine koyuyor musun? Sen bu adamı seviyorsun da karısı
sevmiyor mu? Sevmeseydi, bu duruma katlanır mıydı? Sen katlanır
mıydın? Şimdi yeni biri varmış hayatında. Ve nasıl oluyorsa artık, bu
adam da evliymiş. Kızım bekâr erkek mi kalmadı? Oysa çok gençsin
henüz. İlk ilişkine başladığında 18 'indeymişsin. Hâlâ ders alamadın
mı? Hem iki erkeği bir arada idare etmek nasıl şey? Birbirlerini öğ-
renseler de, öğrenmeseler de çok büyük bir hata değil mi? Kendini
yalnız hissetmen çok doğal. Çünkü gerçekten yalnızsın. Her ikisi de
evlerine, karılarının yanına döndüğünde, sen yalnız kalıyorsun elbette.
Ve ısrar edersen, ömür boyu yalnız kalmaya mahkûmsun bence. Yazık 
değil mi sana? (Güzin Abla, 2011, Şubat, 1).

\section{Üçüncü Mektuba Güzin Abla'nın Verdiği Yanıtın ADDT'nin}

\section{Temel Kavramları Açısından İncelenmesi}

Güzin Abla'nın yanıtında akılcı olmayan inanç ögeleri bulunmaktadır.

Hayatını çalan adam, yalnızsın ifadeleri ile diğerlerine genel etiketler yapıştırılmış ve bütün durum bu nitelemenin ışığında değerlendirilerek damgalama yapılmıştır. Aynı zamanda ömür boyu yalnız kalmaya mahkûmsun, yorumu ile her şeyin kötüye dönüşeceği öngörülerek falcılık ve felâketleştirme yapılmış, olması muhtemel diğer sonuçlar hesaba katılmaksızın gelecek hep olumsuz olarak görülmüştür.

"Karısı sevmeseydi, bu duruma katlanır miydl?" sorusuyla diğer insanın ne düşündüğü bilinmeye çalışılarak zihin okunmaya çalış11mıștır.

\section{Dördüncü Mektup (18 Mayıs 2011)}

10 aydır ilişki yaşadığım erkek arkadaşım, askere gidince çok değişti. Eskisi gibi sevgi dolu değil. Sanki orada beni unuttu.

Sevgili ablacığım, ben 21 yaşında bir genç kızım. 10 aydır bir gençle birlikteyim. Erkek arkadaşım, ilişkimizin başlarında bana çok düşkündü. Benimle görüşmeden, sesimi duymadan yapamıyordu. Kendisi şu anda askerliğini yapıyor ve askere gittiğinden beri bana karşı soğuk. Eskisi gibi sevgi dolu değil. Sanki orada beni unuttu... Belki de ben yanlış düşünüyorum; ama o eski sevdiğim değil. Ben aramazsam, beni aramıyor. Aradığım zaman da eskisi gibi sıcak davranmıyor. Gitmeden önce evliliği düşünüyor, hayaller kuruyorduk. Şimdi bu konuda tek kelime ettiği yok. Ne mektup yazıyor ne de telefon ediyor. Ne dersiniz, benden uzaklaşmış olabilir mi? Çevremdekiler askere giden erkeğin sevgisinin bittiğini, hatta gönüllerinin bir başkasına kaydığını söylüyor. Ben inanmak istemiyorum; ama yine de bu tutumu karşısında çok en- 
dişeleniyorum (Güzin Abla, 2011, Mayıs, 18).

\section{Dördüncü Mektubun ADDT'nin Temel Kavramları Açısın-}

\section{dan İncelenmesi}

A-Başlatan Olay: Sevgilinin askere gitmesi

C-Sonuç: Endişe, kaygı

B-İnanç: Eskisi gibi sevgi dolu değil, çok değişti, bana çok düşkündü, askerde benden soğudu, hep benim aramam lâzım, soğuk, evliliği düşünmüyor, benden uzaklaştı, çevremdeki insanlar da sevgisinin bitebileceğini, başkasına gönlünün kayabileceğini destekliyor, inanmak istemiyorum, yanlış düşünüyor olabilirim.

Kişinin inançlarının, hatalı, kanıtlarla desteklenmeyen, aşırı genelleştirmeler içeren, zorlayıcı, dogmatik, yıkıcı duygular üreten ve amaca ulaşmayı engelleyen akılcı olmayan pek çok özellik taşıdığ 1 görülmektedir.

Ya hep ya da hiç biçiminde (ikili) düşünme: Kişinin (Eskiden bana çok düşündü, hep sesimi duymak isterdi; ama şimdi hiç aramıyor..) bu durumu çok kötü olarak yorumlaması. İlişkisini iki uç bağlamında değerlendirmektedir, ya bana çok düşkün olacak ya da soğuyacak. Bu durum da sorun çözme yollarını tıkar ve felâketleştirmeye yol açar.

Aşırı genelleme: Kişinin, birkaç olayı temel alarak, (kendisini aramamasını, çevresindekilerin askere giden değişir, sözlerini) elinde hiçbir kanıt olmaksızın genel bir kurala inandığı ve bunu izlediği görülmektedir. 
Kişinin, bu kadar olumsuz sonuç çıkarmasına yarayacak veriler olmamasına rağmen yaşadıklarını olumsuz olarak yorumladığı kısaca keyfi çıkarsama yaptığı görülmektedir.

Falcılık yapma: Kişinin küçük bir kanıttan yola çıkarak (sevgilisinin kendisini eskisi gibi aramaması) o kanıtı yeterince değerlendirmeden ve olması muhtemel diğer sonuçları hesaba katmaksızın durumu hep olumsuz olarak öngördüğü görülmektedir. Kişi sevgilisinin kendisiyle evlenmekten vazgeçtiğini düşünmektedir.

Kişi, endişeli olduğunu söylemektedir. Ayrıca yaşadığı olayda hep olumsuz yanlar görmesi, sevgilisinin aramaması olayını başka olumsuz olaylar yaratarak büyütmesi, başkalarının söyledikleriyle şüphelerinin büyümesi kişinin kaygılandığını da göstermektedir. Kaygılanma sağlıklı olmayan olumsuz bir duygudur ve akılcı değildir. Bu duygu bireyi amaçlarına ulaşmaktan alıkoyar.

\section{Dördüncü Mektuba Güzin Abla'nın Yanıtı}

Bence sen biraz hayal dünyasında yaşıyor gibisin kızım. Bu genç adam askerlik yapıyor, tatile çıkmış değil. Çok ciddi bir görev yapıyor ve tabii ki orada, senin yanında olduğu gibi rahat hareket edemiyor. Seni araması pek de kolay olmayabilir. Sen aradığında ise sana duygularını açıklayacak bir ortam bulamıyordur belki. Yanında arkadaşları, kumandanı, çekineceği birileri varsa, elbette senin yanında olduğu gibi sevecen davranamayacaktır. Mektup yazmaya gelince... Bazı kişiler mektup yazmaktan hiç hoşlanmazlar. Hele şimdiki gençler, duygularını kolay kolay kaleme alamıyorlar. Yazmak onlara çok zor geliyor. Ya da mesaj atar gibi kısa, duygusuz, özet birkaç sözcükle yetiniyorlar. Asıl sen, onun sevgine, şefkatine, sıcaklığına ihtiyacı olabileceğini hiç aklına getirmiyor musun? Düşün ki, o ailesinden, sevdiklerinden, sıcak yuvasından uzakta, disiplinli ve zor bir görev yapıyor. Elbette senin sevgine, yakınlığına ihtiyacı var. Kızım, bir gencin askerlik görevi sırasında ne kadar sorunlu, ne kadar hassas ve ne kadar ilgiye muhtaç olduğunu bilemezsin. Onu sorgulamak yerine; ona en sevecen duygu- 
larınla sevimli, hoş mektuplar yaz. Özlemini, sevgini dile getir. Sitem edeceğine ona destek olmaya çalış (Güzin Abla, 2011, Mayıs, 18).

\section{Dördüncü Mektuba Güzin Abla'nın Verdiği Yanıtın}

\section{ADDT’nin Temel Kavramları Açısından İncelenmesi}

Mektuba Güzin Abla'nın verdiği yanıtın koşullu, duruma göre değişen ifadeler içerdiği, esnek olduğu, yapıcı duygular ürettiği ve amaca ulaşmayı kolaylaştıran akılcı inançlara sahip olduğu görülmektedir (Seni kolayllkla arayamayabilir, konuşacak ortamı olmayabilir, mektup yazmayl sevmeyebilir vb.).

Mektupta ayrıca şimdiki gençlere yazmak zor geliyor, kısa, duygusuz birkaç sözcükle yetiniyorlar, askerlikte kişi sorunlu ve hassas olur düşünceleri ise zorunluluk içeren ifadelerdir, aşırı genelleştirme ve damgalama yapılmıştır.

\section{Beşinci Mektup (23 Ağustos 2011)}

Ben 35 yaşındayım, erkek arkadaşım ise 24. Birbirimizi çok seviyor, evlenmek istiyoruz. Ancak ailelerimiz ilişkimize karşı çıkıyor. Ablacığım, ben 35 yaşında bir okurunuzum. Yaşımı pek göstermiyorum. Bu yaşıma kadar bir-iki kişiyle çıktım, hiçbiri ciddi değildi, hepsi yalan doluydu. Şimdi birini çok seviyorum. O da beni çok seviyor. Âşı̆̆ız birbirimize; ama en büyük sorunumuz yaş farkı. Erkek arkadaşım 24 yaşında. Bu yüzden önce kabul etmedim, direndim ama o beni bu ilişkinin yürüyeceğine inandırdı. Çıkmaya başlayalı iki ay oldu ve biz evlilik kararı aldık; ama onun ailesi ilişkimize kesinlikle karşı çıkıyor. Benim annem durumu henüz bilmiyor, sadece kız kardeşim biliyor. $\mathrm{O}$ da bana destek olur derken, erkek arkadaşıma beni bırakması için baskı yaptı. Şu ân ikimiz de o kadar kötüyüz ki, o orada, ben burada sürekli ağlıyoruz. Üç günde üç kilo verdim... Sevgilim de çok üzülüyor. "Buralardan gidelim." diyor; ama nasıl gideceğiz? İkimiz de her şeyin farkındayız ablacığım, dengi dengine evlenenleri de görüyoruz. Çok zor durumdayım, ne yapacağımız hakkında en ufak bir fikrim yok. Onsuz kalmak çok acı olacak biliyorum. Sizce yanlış yolda mıyız? Aileleri dinleyip ayrılmalı mıyız, yoksa gidebildiğimiz yere kadar gitmeli miyiz? (Güzin Abla, 2011, Ağustos, 23). 


\section{Beşinci Mektubun ADDT'nin Temel Kavramları Açısından İncelenmesi}

A-Başlatan Olay: Sevgilisi ile arasında 11 yaş fark olması

C-Sonuç: Üzüntü, tasalanma, kaygı, ağlama, kararsızlık, dışlanmışlik

B-İnanç: Birbirimizi çok seviyoruz, yaşımı göstermiyorum, ailelerimiz ilişkimizi istemiyor, hep yalan dolu ilişkiler yaşadım bu gerçek, yaş farkı sorun, ona direnemedim, beni ilişkiye inandırdı, buralardan gidemeyiz, dengi dengine evlenenler de mutlu olamıyor, onsuz kalmak çok acı olacak, yanlış yolda mıyım?

Kişinin inançlarında kesin, aşırı genelleştirmeler içeren, sert ve zorlayıcı, yoğun ve yıkıcı duygular üreten, amaca ulaşmayı engelleyen akılcı olmayan inançların yer aldığg görülmektedir.

Hep yalan dolu ilişkiler yaşadım bu gerçek, dengi dengine evlenenler de mutlu olamıyor inançlarıyla kişinin aşırı genelleştirme yaptığ 1 görülmektedir.

Onsuz kalmak çok acı olacak inancıyla kişi, ya hep ya da hiç biçiminde düşünmekte ve aynı zamanda falcılık yapmaktadır. Yaşantısını iki uç bağlamında değerlendirmektedir.

Buralardan gidemeyiz, onsuz kalmak çok acı olacak inançları zorunluluk içeren ifadelerdir.

Kişinin yaş farkından dolayı sorun yaşayacağına olan inancıyla olumsuza odaklandığı, olumsuz tek bir ayrıntıyı bütünün içinden 
ayıkladığ 1 ve yalnızca ona odaklandığı görülmektedir. Bu inanç aynı zamanda kişinin olayı korkunç görmesine, sorun çözme becerilerini elinden almasına, sorunu çözülemeyecek kadar büyük algılamasına neden olmaktadır.

Kişinin inançlarına paralel olarak yaşadığı duygulardan "kaygı", olayın olumsuz yanlarını abartmasına, çözüm yolları üretememesine neden olan sağlıksız olumsuz duygudur. Bunun yanı sıra üzülmek, tasalanmak uyumu bozmayan sağlıklı olumsuz duygular arasındadır.

\section{Beşinci Mektuba Güzin Abla'nın Yanıtı}

Sevgili kızım, eğer bu mektubu bana 15-20 yıl önce yazmış olsaydın, sana "Aranızdaki yaş farkı yüzünden mutsuz olursunuz, toplum tarafindan da hoş karşılanmazsınız." diye cevap verebilirdim. Ama günümüzde bu konudaki anlayış o kadar değişti ki, artık kimse yaş farkının mutluluk için engel yarattığını düşünmüyor. Eski katı kurallar giderek silindi. Bir bakıyorsunuz, aralarında 20 yaş bulunan çiftler inanılmaz bir uyum sağlıyor, evliliklerini yıllarca herkese inat sürdürüyor. $\mathrm{Bu}$ yüzden kızım, madem birbirinizi bu kadar seviyorsunuz, bence gidebildiğiniz yere kadar gidin, kimseye aldırmayın. Sen artık olgun bir kadınsın, sevdiğin de reşit bir genç adam. Birbirinizi tamamladığınıza inanıyorsanız evlenin. Aileleriniz de sonunda mutluluğunuzu görüp direnmekten vazgeçecektir. Herkese inat, sevginin her engeli yıkabildiğini ispatlayın... (Güzin Abla, 2011, Ağustos, 23).

Beşinci Mektuba Güzin Abla'nın Verdiği Yanıtın ADDT'nin

\section{Temel Kavramları Açısından İncelenmesi}

Mektuba Güzin Abla'nın verdiği yanıtın koşullu, duruma göre değişen ifadeler içerdiği, esnek olduğu, yapıcı duygular ürettiği, arzu, istek, tercih içerdiği, orta düzeyde ve yapıcı duygular üreten ve amaca ulaşmayı kolaylaştıran akılcı inançlara içerdiği görülmektedir ( $\mathrm{Za}$ manla yaş farkı konusundaki anlayışın değiştiği, birbirinizi tamamladığınıza inanıyorsanız evlenin.). Mektupta ayrıca artık kimse yaş far- 
kının mutluluk için engel yarattığını düşünmüyor, sevginin her engeli yıkabildiğini ispatlayın ifadeleri, aşırı genelleştirme ve damgalama içermektedir ve akılcı olmayan inançlardır. Ayrıca aileniz mutluluğunuzu görüp direnmekten vazgeçecektir ifadesiyle de zorunluluk içeren, dayatmacı bir akılcı olmayan inanç ortaya konmuştur.

\section{Sonuç ve Tartışma}

Güzin Abla köşesine gelen ve incelenen mektupların konularının sevgiliden ayrılma, evli birisi ile ilişki yaşama, terk edilme, yaş farkı, iletişim problemleri gibi konulardan oluştuğu görülmüştür. Mektupları yazan kişilerin genellikle, üzüntü, karasızlık, endişe, kaygı, pişmanlık, tasalanma gibi duygularla mektup yazdıkları ve Güzin Abla'dan yardım talebinde bulundukları, pek çok mektupta da açıkça kişinin ne yapması gerektiği konusunda Güzin Abla'nın düşüncesini sorduğu görülmüştür. Okuyucu mektuplarının ve cevap mektuplarının inanç özellikleri açısından genellikle akılcı olmayan pek çok öge taşıdığ ortaya çıkmıştır. Mektuplar, genellikle aşırı genelleştirme, dayatmacıl1k, felâketleştirme, olumsuza odaklanma, ikili düşünme (ya hep ya hiç), geleceği ön görme (falcılık), keyfî çıkarsama gibi akılcı olmayan pek çok inanç özelliğine sahiptir. Genellikle akılcı olmayan inançlar, olumsuz, sağlıksız duyguların oluşmasına neden olur ve bu da bireyleri amaçlarına ulaşmaktan alıkoyar, hayatlarının tadını kaçırır ve kişinin kendine zarar veren davranışlarda bulunmasına neden olabilir. Sağlıklı olmayan olumsuz duygulara, fizyolojik açıdan, birçok otonom sinir sistemi belirtisi eşlik eder. Davranışsal açıdan, kişinin kendisine zarar veren birtakım davranışlarına yol açabilir ya da kişinin sorun çözme 
becerilerini ketleyebilir; dolayısıyla kişi kitlenip kalmış, sıkışmış, çaresiz, eli kolu bağlı bir durumda kalabilir. Bilişsel açıdan, aşırı yüklü, akılcı olmayan düşüncelerle birlikte bulunurlar. Toplumsal açıdan, başkalarında, eşduyum ya da dayanak olma yerine cezalandırma ya da kaçınma davranışları doğurma olasılığı daha yüksektir (Köroğlu, 2011).

Güzin Abla'nın akılcı olmayan inançlarla yazılan mektuplara büyük bir çoğunlukla akılcı olmayan inançlarla cevaplar verdiği görülmüştür. Mektuplara verilen yanıtlarda bireylerin bakış açıları genişletilmeye ya da değiştirilmeye çalışılmamış; aksine sert ve zorlayıcı sonuçlarla, katı ve kesin bir şekilde ne yapmaları gerektiği bireylere söylenmiştir. Cevap mektuplarının yardım arayan daha akılıı inançlara sahip olabilmelerine yardımcı olabilecek nitelikte olmadığı görülmüştür.

İncelenen hemen hemen her cevap mektubu dayatmac1, zorunluluk içeren ifadelerle noktalanmıştır.

İncelenen mektuplar göstermiştir ki insanlar genellikle başlarına gelen bir olaydan dolayı acı çektiklerini ya da olumsuz durumlarla karşılaştıklarını düşünmektedirler. ABC Modeli'nin aksine insanlar karşılaştıkları sonuçları direkt olarak yaşadıkları olaya bağlamaktadırlar, kendi inançlarının ya da düşüncelerinin yaşadıkları sonuçtaki etkisini göz ardı etmektedirler ya da farkında değillerdir.

\section{Öneriler}

Güzin Abla Köşesi, uzun yıllardan beri varlığını sürdürmektedir 
ve insanlar yardım alabileceklerini düşünerek bu köşeye sorunlarını yazmaktadır. Aşk ve ilişkiler konusunda gelen okuyucu mektuplarına yazılan cevap mektuplarının genellikle akılcı olmayan inanç özellikleri taşıdığı, sağlıksız olumsuz duygular üretebilecek nitelikte olduğu görülmüştür. Yardım arayan kişilerin sorunlarına yine akıldışılığı destekleyebilecek nitelikte, düşünsel çarpıtmalar içeren, yaratıcı problem çözmesinin önünü tıkayabilecek nitelikte olan cevap mektuplarının sorumluluğu kime aittir? Bu bir etki araştırması değildir, okuyucuların üzerindeki etkilerinin incelenmesi başka bir araştırmanın konusudur. Ancak inceleme sonucunda çıkan sonuç göstermiştir ki Güzin Abla Köşe'sine gelen mektupların alanında uzman kişilerin yardımıyla yanıtlanmasının ve mektup yazan kişilere uzmanlardan da destek almaları önerisinin yapılmasının önemli olduğu düşünülmektedir. Bunun yanı sıra bireylerin problem çözme becerilerinin geliştirilebilmesi, kendini olduğu gibi kabul edebilmesi, esneklik kazanabilmesi ve belirsizlikleri kabul edebilmesi, risk alabilmesi, gerçekçi beklentiler içinde olabilmesi, engellenme eşiğinin yüksek tutulabilmesi, kendi sorumluluğunu taşıyabilmesi için öğrencilere, ailelere ve öğretmenlere yönelik olarak akılcı duygusal davranışçı eğitimin verilmesinin ve bu konuda medyanın daha aktif ve sorumlu davranmasının önemli olduğu düşünülmektedir.

\section{Kaynakça}

Akın, A. (2009). Akılcı duygusal davranışçı terapi odaklı grupla psikolojik danışmanın psikolojik iyi olma ve öz-duyarlık üzerindeki etkisi. Yayınlanmamış doktora tezi, Sakarya Üniversitesi. 
Altun, E. (2006). Akllcr duygusal temelli güvengenlik eğitiminin ilköğretim beşinci sinıf ögrrencilerinin akılcı olmayan inanç ve güvengenlik düzeylerine etkisi. Yayınlanmamış yüksek lisans tezi, Gazi Üniversitesi.

Avcı, Ü. (7 Şubat 2003). Güzin Abla'dan tavsiye erkeklere güvenmeyin. 17 Kasim 2014, http://www.milliyet.com.tr/2003/02/07/yasam/yas00.html.

Corey, G. (2008). Psikolojik danışma, psikoterapi kuram ve uygulamaları. (T. Ergene, Çev.). Ankara: Mentis Yayıncılık.

Çivitçi, A., Türküm, A. S., Duy, B. ve Hamamc1, Z. (2009). Okullarda akılcı-duygusal davranış terapisine dayalı uygulamalar kavramlar, teknikler ve örnek etkinlikler. Ankara: Pegem Akademi Yayıncılik.

Dryden, W. ve Neenan, M. (2004). The rational emotive behavioural approach to therapeutic change. London: Sage Publications.

Ellis, A. (1994). Akılc1-duygusal terapide yansımalar (S. Türküm, Çev.). Ankara Üniversitesi Ĕ̈itim Bilimleri Fakültesi Dergisi, 27(2), 969-974.

Ellis, A. (1995). Changing rational-emotive therapy (RET) to rational-emotive behavior therapy (REBT). Journal of Rational-Emotive \& Cognitive-Behavior Therapy, 13(2), 85-89.

Ellis, A. (2002). The role of irrational beliefs in perfectionism. G. L. Flett ve P. L. Hewitt (Eds.), Perfectionism: Theory, research, and treatment içinde (217-229). Washington, DC: American Psychological Association.

Ellis, A., ve Dryden, W. (1997). The practice of rational emotive therapy. New York: Springer.

Güzin Abla. (23 Ağustos 2011). Güzin Abla. Hürriyet. 30 Ocak 2013. http://www.hurriyet.com.tr/magazin/yazarlar/18553333.asp. 
Güzin Abla. (18 Mayıs 2011). Güzin Abla. Hürriyet. 30 Ocak 2013. http://www.hurriyet.com.tr/magazin/yazarlar/17811697.asp.

Güzin Abla. (25 Ocak 2011). Güzin Abla. Hürriyet. 30 Ocak 2013. http://www.hurriyet.com.tr/magazin/yazarlar/16842496.asp.

Güzin Abla. (3 Ocak 2011). Güzin Abla. Hürriyet. 30 Ocak 2013. http://www.hurriyet.com.tr/magazin/yazarlar/16667367.asp.

Güzin Abla. (1 Şubat 2011). Güzin Abla. Hürriyet. 30 Ocak 2013. http://www.hurriyet.com.tr/magazin/yazarlar/16902134.asp.

Hamamcı, Z., Murat, M., Yıkımaz, M. ve Çekiç, A. (2008). Bir içerik analizi örneği: Güzin Abla köşesine gelen mektuplar ve bu mektuplara verilen yanıtların incelenmesi. Dokuz Eylül Üniversitesi Buca Eğitim Fakültesi Dergisi, 23, 63-68.

Husaini, B. A., Moore, S. T. ve Cain, V. A. (1994). Psychiatric symptoms and help seeking behaviour among the elderly: An analysis of racial and gender differences. Journal Of Gerontological Social Work, 21, 177-195.

Köroğlu, E. (2011). Düşünsel duygulanımcı davranış terapisi (3. bask1). Ankara: HYB Basım Yayın.

Nelson-Jones, R. (1982). Danışma psikolojisi kuramları. (F. Akkoyun, V. Duyan, S. Doğan, B. Eylen ve F. Korkut, Çev.). Ankara: Cassel Educational Limited. (Orijinal çalışma basım tarihi 1982).

Oğurlu, U. (2006). Düşünsel duygulanımcı davranış terapisi (DDDT) odakl grupla psikolojik danışmanın ergenlerdeki benlik saygısı düzeyine etkisi. Yayımlanmamış yüksek lisans tezi, Mersin Üniversitesi.

Özkorumak, E., Güleç, H., Köse, S., Borckardt, J., ve Sayar, K. (2006). Depresyon hastalarında tıp dışı yardım arama davranışı: Aleksitimi bir etken olabilir mi? Klinik Psikiyatri, 9, 161-169. 
Psikoloji Portalı. (13 Mayıs 2010). Psikolog veya Psikiyatra Gidememenizin En Önemli Nedeni Nedir? Anket Sonuçları ve Yorumları. 30 Ocak 2013,

http://www.psikoloji.gen.tr/content.php?23-Psikolog-veya-Psiki yatra-gidememenizin-en-\%C3\%B6nemli-nedeni-nedir-(-Anketsonu\%C3\%A7lar\%C3\%BD-ve-Yorumlar\%C3\%BD).

Türkçapar, M. H. (2008). Bilişsel terapi (3. baskı). Ankara: HYB Basim Yayın.

Ünal, S., Kaya, B. ve Yalvaç, H. D. (2007). Psikotik hastalarda hastallk açıklama modeli ve çare arama davranışı. Türk Psikiyatri Dergisi, 18, 38-47.

Yaşan, A. ve Gürgen, F. (2004) Psikiyatri ve fizik tedavi polikliniklerine başvuran hastaların geleneksel yardım arama davranışının karşılaştırılması. Dicle Tıp Dergisi, 31, 20-28.

Yıldırım, A. ve Şimşek, H. (2003). Sosyal bilimlerde nitel araştırma yöntemleri. Ankara: Seçkin Yayıncılık.

Ziegler, D. J. (2003). The concept of psychological health in ration al emotive behavior therapy. Journal of Rational-Emotive and Behavior Therapy, 21, 21-36. 